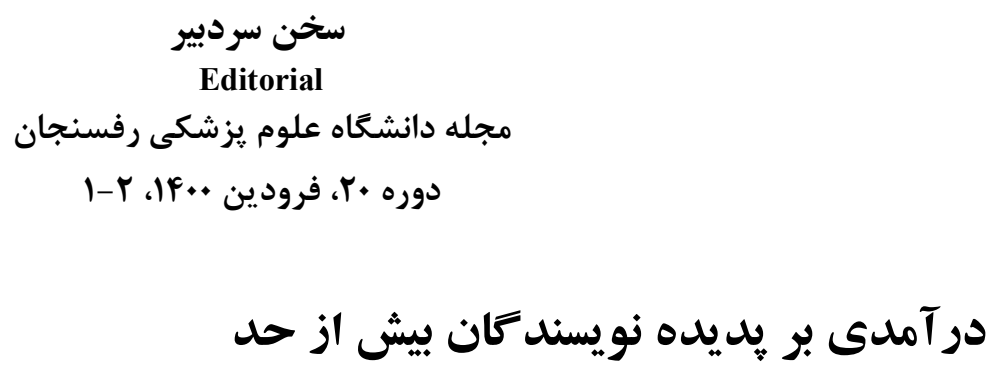

Editorial

مجله دانشعاه علوم يزشكى رفسنجان

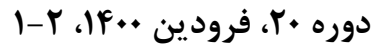

در آملى بر يليده نويسند Fان بيش از حد

\title{
An Introduction to Hyper-authorship Phenomenon
}

\section{محسن رضائيان'}

\section{Rezaeian}

اصطلاح نويسندَان بيش از حد (Hyper-authorship) يا (Mass-authorship) براى مقالاتى مورد استفاده قرار مى كيرد كه تعداد نويسندكان آنها از حد متعارف، بسيار فراتر رفته باشد. اگر جه شايد نتوان حد متعارفى براى تعداد نويسندكان يك مقاله مشخص نمود، شواهد موجود نشان مىدهند كه تعداد مقالاتى كه نويسندًان آنها از هزار نفر بالاتر مىباشد، در حال رشد Institute for Scientific فزآيندهاى هستند. مطالعه به عمل آمده بر روى مقالات نمايه شده در انستيتو اطلاعات علمى

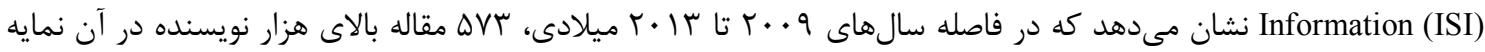

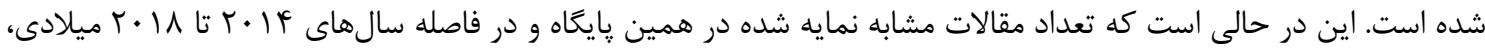

$$
\text { به بيش از دو برابر، يعنى هاس إ مورد افزايش يافته است [1]]. }
$$

نوشتن مقالات با بيش از هزار نويسنده در فيزيك ذرات و فيزيك اتمى (Particle and nuclear physics) به خاطر وجود يروزههاى بزرگ جند مليتى، از قدمت بيشترى برخوردار است. با اين وجود و در سالهاى اخير، نغارش خنين مقالاتى در حوزهاى ديغر از دانش بشرى از جمله إيدميولوزى جهانى (Global epidemiology) و تغييرات آب و هوايى Climate)

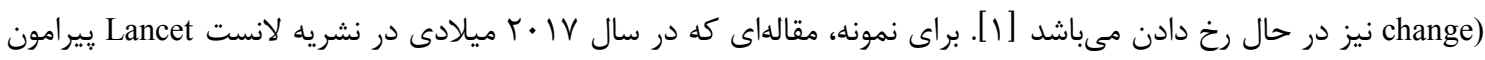
شاخص توده بدنى (Body-mass index) به رشته تحرير درآمده است، داراى بيش از . ‥ انويسنده از .. إ كشور جهان مى باشد [r].

اكر جه افزايش تعداد نويسندكان يك مقاله مىتواند به معناى انجام يروزههاى يزوهشى بزرگتر و همكارىهاى بين المللى بيشترى باشد، با اين وجود، ضرورى است كه تك تك نويسندگان اين مقالات نيز از معيارهاى نويسندكى برخوردار باشند [ـ].

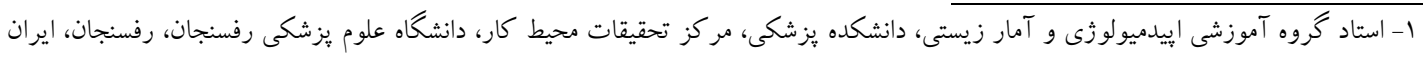

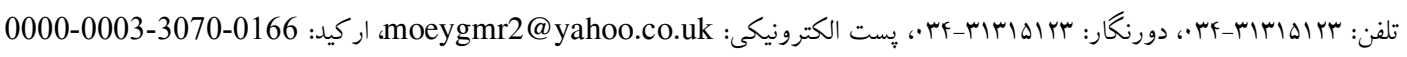


در خاتمه اين سخن سردبيرى ضرورى است كه يكبار ديگر نگاهى به معيارهاى نويسندگى يك مقاله داشته باشيه. كميته بينالمللى سردبيران مجلات علوم يزشكى International Committee of Medical Journal Editors (ICMJE) معيارهاى نويسندكى در يك مقاله را به شرح زير بيان نموده است [ب]:

ا. نويسنده فردى است كه سهم اساسى در شكل اطلاعات داشته باشد.

r. وى همرجنين مىبايست در تهيه پيشنويس اوليه مقاله نقش داشته و يا اين كه پيشنويس اوليه را به شكلى نقادانه از نظر بار معنوى آن مورد تجديدنظر قرار دهد. r. نويسنده بايستى نسخه نهايى مقاله را قبل از خابٍ مورد تأييد نهايى خود قرار دهد.

fا. بالاخره، نويسنده يك مقاله بايد خود را ياسخ گو درباره جنبه هاى مختلف يك مقاله قلمداد نمايد. وى بايد اين اطمينان را ايجاد نمايد تا سؤالاتى كه پيرامون صحت و تماميت مقاله مطرح مى گردد، به بهترين نحو مورد بررسى و ياسخ گويى قرار خواهد خرفت.

\section{References}

[1] Dalmeet Singh Chawla. Hyperauthorship: global projects spark surge in thousand-author papers. Nature. Dec 13. doi: 10.1038/d41586-019-03862-0. Online ahead of print.

[2] NCD Risk Factor Collaboration (NCD-RisC). Lancet 2017; 390: 2627-42.

[3] Deborah Bowman D, Kinnan S. Authorship of articles in scholarly publications. VideoGIE 2019; 31; 5(1): 5-6.

[4] ICMJE. Defining the role of authors and contributors. Available at: http://www.icmje.org/recommendations/ browse/roles-and-responsibilities/defining-the-role-of-authors-and-contributors.html. Accessed February, 2021. 